\title{
Present Day Mutations Show Theoretical Possibility of Various Human Hair Appearances Arising from a Pristine Human Hair Type in Antiquity
}

\section{Seun Ayoade*}

Physiology, University of Ibadan, Nigeria

Received: 眥June 03, 2018; Published: 钢 June 11, 2018

*Corresponding author: Seun Ayoade, BSc (Hons) Physiology, University of Ibadan, P.O. Box 22325, Oyo State, Nigeria.

\section{Opinion}

It is quite obvious that the different ethnicities on earth today exhibit various hair appearances. Such appearances include straight, wavy, curly etc. How did this come about? According to creationists all of humanity is descended from just two people and variations among mankind (according to some creationists) arose via inbreeding. [1,2] How viable is this hypothesis, scientifically speaking?

That mutations can change hair appearance is demonstrated by the following hair related conditions: Also, normal variations (polymorphisms) in the genes EDAR, FGFR2 and TCHH appear to affect hair texture (Table 1). [3] The above show it is theoretically possible that the different appearances/textures of human hair on earth today could have arisen from a pristine hair appearance/ texture via mutations triggered by inbreeding.

Table 1.

\begin{tabular}{|c|c|}
\hline Hair Condition & Associated Mutation \\
\hline Uncombable Hair Syndrome & $\begin{array}{c}\text { mutations in the PADI3, TCHH, or TGM3 } \\
\text { gene }\end{array}$ \\
\hline Monilethrix & $\begin{array}{c}\text { mutations in the DSG4, KRT81, KRT83, } \\
\text { or KRT86 gene }\end{array}$ \\
\hline Keratoderma with woolly hair & $\begin{array}{c}\text { caused by mutations in the JUP, DSP, } \\
\text { DSC2, or KANK2 gene }\end{array}$ \\
\hline $\begin{array}{c}\text { Autosomal recessive } \\
\text { hypotrichosis }\end{array}$ & $\begin{array}{c}\text { caused by mutations in the DSG4, LIPH, } \\
\text { or LPAR6 gene }\end{array}$ \\
\hline
\end{tabular}

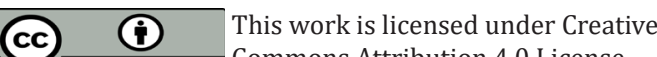

To Submit Your Article Click Here: $\quad$ Submit Article DOI: $10.32474 /$ PRJFGS.2018.01.000116

\section{References}

1. Mister SA (2018) If the Bible is Literally True, Adam and Eve were Most Likely Platinum Blonde Caucasians. JOJ Nurse Health Care 6(3): 1-2.

2. Mister Seun Ayoade (2018) Present Day Mutations Prove Theoretical Possibility of Prehistoric/Historical Emergence of East Asian Phenotype from Caucasians via Inbreeding. JOJ Nurse Health Care 6(5): 1-2.

3. Fujimoto A, Kimura R, Ohashi J, Omi K, Yuliwulandari R, et al. (2008) A scan for genetic determinants of human hair morphology: EDAR is associated with Asian hair thickness. Hum Mol Genet 17(6): 835-843.

4. Fujimoto A, Nishida N, Kimura R, Miyagawa T, Yuliwulandari R, et al. (2009) FGFR2 is associated with hair thickness in Asian populations. J Hum Genet 54(8): 461-465.

5. Medland SE, Nyholt DR, Painter JN, McEvoy BP, McRae AF, et al. (2009) Common variants in the trichohyalin gene are associated with straight hair in Europeans. Am J Hum Genet 85(5): 750-755.

6. Shimomura Y, Christiano AM (2010) Biology and genetics of hair. Annu Rev Genomics Hum Genet 11: 109-132.

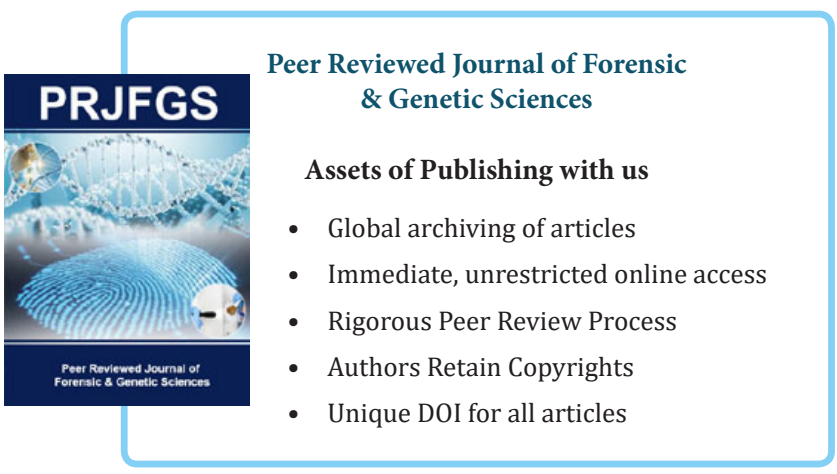

